14,000 students are pursuing graduate courses. Many are themselves teachers on release from other universities all over Brazil, giving Campinas the reputation of a "school for schools'. Second, researchers are encouraged to build their own links with industry and even to profit from them. Campinas was the first university to set up a patent office to protect its staff's discoveries (a move which has still found few imitators). Several researchers have set up their own small companies. Third, the university has been aggressive in buying good facilities.

At the the end of last year, it bought an IBM 3090 , giving it the most powerful supercomputer in Latin America. Next, as soon as federal funds are available, will come the National Synchrotron Light Facility. From the beginning it has had the National Center for Research in Telecommunications.

In 1986 it created a large biotechnology institute at the stroke of a pen by buying nearby Monsanto Corporation's Agricultural Research Center. Later, it complemented the centre with a Genetic and Molecular Engineering Center to train people for the expected expansion in biotechnology. Now there is an multidisciplinary programme centred around biotechnology, alongside similar integrated schemes in computers, fine chemicals, energy and new materials. The rector, Paulo Renato Costa Souza, says that his univerity's philosophy of trying to build integrated programmes, instead of letting everyone submit individual grants, is "completely new in the university system".

chance to examine structures in Antarctica to which Brazil was once joined. Overall, the impression at USP is of a university that is only occasionally at the international frontiers but is frequently not far behind them.

But like researchers elsewhere, USP staff are held back by petty import restrictions. Some laboratories - the Institute of Chemistry is one - employ several people simply to do the paperwork. But the delay remains. Ana Clara Schenberg, a yeast geneticist at the Institute of Biomedical Sciences, has been waiting for one piece of equipment for four years. It is already obsolete.

Life is particularly difficult for molecular biologists. Even things such as dry ice are in short supply and items that need to be used quickly - short-lived isotopes, for example - are almost unobtainable. And, worst of all, delay destroys flexibility. "If you need to change your research programme, just forget it", says molecular biologist Bianca Zingales. Everything has to be planned ahead around the import of reagents.

Many highly trained young researchers are now returning from abroad, thanks to earlier government decisions to invest in foreign fellowships, offering the chance to push the university ahead. Unfortunately,

\title{
Biomedicine with a bite
}

\section{São Paulo}

SNAKES, scorpions and spiders make the Institute Butantan famous. Its serpentarium is São Paulo's most popular tourist attraction and every year thousands of people from all over Brazil send to the institute snakes and other exotic creatures they have found in field or garden.

The snakes are essential for Butantan's function as the main supplier of antivenom in Brazil. Venom is milked from the snakes and used to hyperimmunize horses (the institute keeps 700 at stables outside São Paulo); a specific gamma globulin fraction containing antibodies against the venom is later extracted from the horses' blood. The institute maintains a small hospital, manned 24 hours a day, with a helicopter pad in front of it.

People bitten in the São Paulo region are rushed here - treatment within the first three hours is most effective. Brazil has an impressive array of poisonous snakes and more than : : 30,000 people are bitten each year. :

Snakes are not the institute's $\frac{\text { I }}{0}$ only concern. Butantan is essentially a large biomedical research institute joined with a production facility. As well as snake antivenoms, it produces 16 kinds of vaccine. Its 1,300 staff are divided among 20 different departments of basic research and a new Centre of Biotechnology.

Naturally enough, some of its key projects involve improving vaccines. One involves cloning polio virus in vaccinia with the eventual aim of constructing a single-shot vaccine cocktail for polio, measles, hepatitis B, Willy Beçak and one of his Butar diphtheria, tetanus and whooping production workers. cough. Another is to develop a genetically | cate reagents manufactured in Brazil.

the returning researchers often seem quite lost - particularly those who have been at top US laboratories.

Around the campus, young people in various stages of 'returnee's syndrome' can be met. Salete Newton, who returned from a postdoctoral fellowship at Stanford University three months ago, is in the fairly early stages. "You don't know what to do", she says, "you know everything will take ten times longer than in America. There the limit is your imagination, here you are trapped by the limitations of the facilities."

A little later, the returnee struggles to see advantages. "At last I have time to read all those papers", says one. "Maybe it's a good thing that I'm forced to think instead of just rushing onto the obvious experiment", says another. Along comes the thought that one is free. engineered hepatitis-B vaccine, although the institute may decide to buy the technology from abroad. Projects to produce albumin and factor VIII by new techniques are also under way.

Other groups do basic research on venoms (the important vasodilator drug bradykinin was first isolated here), viruses (it is still relatively easy to discover a new virus a day in the rain forest), the genetics of amphibians and reptiles, and the isolation of natural substances from plants and marine animals.

Techniques developed at the institute are transferred free "to anyone seriously interested in production", says the director, Willy Beçak. "We're not interested in profit but to be in the at the frontier", he says; "the idea is for the institute to be an open place for people from universities; often universities are not the right place for transfer to the production sector."

The institute's popularity rose after it opened a 'reagent supermarket' in an effort to counter the effect of import restrictions.

Special permission to import reagents tax-free in bulk, together with a $\$ 1$ million grant from $\mathrm{CNPq}$, enables Butantan to offer immediate delivery of a range of hard-to-import items. But it is not permitted to dupliwould be thought too risky over there, the sort of thing you would only do if you are already a full professor", says molecular biologist Fernando Reinach, who has no symptoms of the syndrome after three years back home. Returnees also come to realize that at USP one can attract the very best students of one's own.

The fully recovered researcher avoids the most internationally competitive areas but is busy inviting foreign colleagues for short stays (provided they agree to smuggle restriction enzymes, short-lived isotopes and the like through the Brazilian customs), using BITNET and facsimile machines to keep up, building a group in an area of his or her own, and sending off students for doctoral training abroad. Of course, there are always a few who never recover and just settle back. . . . 